\title{
Mathematical Modeling of Photovoltaic Module with Simulink
}

\author{
HAIDAR GAFAR ABUGOUKH \\ O.M. Beketov National University of Urban Economy in Kharkov \\ Kharkov, Ukraine
}

\begin{abstract}
Annotation - Solar Energy is a good choice for electric power generation, since the solar energy is directly converted into electrical energy by solar photovoltaic modules Solar cells generates most of their electricity from direct sunlight. However, they also generate electricity on cloudy days and some systems can even generate very small amounts of electricity on bright moonlit nights. Individual solar cells typically only generate tiny amounts of electrical energy. To make useful amounts of electricity, these cells are connected together to make a solar module, otherwise known as a solar panel or, to be more precise, a photovoltaic module.The PV model plays an important role in the accuracy of the time simulation of the PV cell model. Modeling of PV cell involves the estimation of the $I-V$ and $P-V$ characteristics curves to emulate the real cell under various environmental conditions Photovoltaic (PV) model is used in a simulation study to validate the system design of a PV system. This paper presents modeling of Photo- voltaic (PV) module using MATLAB/SIMULINK. The model is developed on the basis of mathematical model of the PV module. The PV module of SN72-CELL-POLY CRYSTALLINE PV MODULE SN325P is selected for the experimental and technical data to analyze the developed model. The output current and power characteristic curves highly depend on some climatic factors such as solar radiation and temperature, are obtained by simulation for the selected module with the output power of $325 \mathrm{~W}$.The objective of this paper is to develop a model to simulate the behavior of a photovoltaic cell. The achieved Voc voltage and current values from I-V and P-V characteristics are compared with module data sheet both models are implemented in MATLAB ISIMULINK. The "five-parameter model" is a performance model for photovoltaic solar cells that predicts the voltage and current output by representing the cells as an equivalent electrical circuit with radiation and temperature-dependent components. An important feature of the five-parameter model is that its parameters can be determined using data commonly provided by module manufacturers on their published datasheets.
\end{abstract}

Keywords - photovoltaic energy; PV Module; Simulink model.

\section{INTRODUCTION}

Support the energy diversification strategy. Reduce Carbon footprint. - Convert desert wastelands into a natural resource environment. Promote sustainability and preserve earth's natural resources by using renewable resources in electricity generation. Contribute to improving the technology used for electricity generation by solar energy. Develop UAE expertise in the field of solar and renewable energy and building. Increase social levels of awareness about climate change and sustainable energy. Promote Research and Development and involve local universities and colleges in the field of renewable energy. Contribute positively towards Dubai's vision, brand, growth, society and environment.

Using solar power will reduce the Carbon footprint compared to current methods using fossil fuels. (Will be reduced to 1 million tons of carbon a year when producing $1000 \mathrm{MW}$ of solar energy with the number of 2000 hours operation).

The Mohammed bin Rashid Al Maktoum Solar Park is the largest single-site solar park in the world, based on the IPP model. It will generate $1,000 \mathrm{MW}$ by 2020 and $5,000 \mathrm{MW}$ by 2030 . The $13 \mathrm{MW}$ photovoltaic first phase became operational in 2013. The 200MW photovoltaic second phase of the solar park was commissioned in March 2017. The 800MW photovoltaic third phase will be operational by 2020 , and the first stage of the 700MW CSP fourth phase will be commissioned in Q4 of 2020.

Capacity: 1000MW, Area: 40.45 KM2.

To reduce levelized cost of electricity (LCOE), eff orts to advance module and balance of system (BOS) technology will focus on increasing energy yield, making heat and light management, durability, and reliability more important. An inherent tension exists between improving these technical factors and reducing the area cost $(\$ / \mathrm{m} 2)$ of the module. Energy yield is proportional to the capacity factor.

The costs of solar PV technology have dropped significantly over the past few decades, primarily driven by technological innovations and global policy support.

Compared with conventional energy generation technologies, renewable technologies are considered young. It is widely accepted that renewable still need financial support for further deployment and for them to reach grid and socket parity with conventional.

\section{SOLAR PV TECHNOLOGY OVERVIEW}

PV cell technologies are broadly categorised as either crystalline or thin-film. Crystalline silicon (c-Si) cells provide high efficiency modules. They are sub-divided into mono-crystalline silicon (mono-c-Si) or multi-crystalline silicon (multi-c-Si). Mono-c-Si cells are generally the most efficient, but are also more costly than multi-c-Si. Thinfilm cells provide a cheaper alternative, but are less efficient.6 there are three main types of thin-film cells: Cadmium Telluride (CdTe), Copper Indium (Gallium) DiSelenide (CIGS/CIS), and Amorphous Silicon (a-Si). The performance of a PV module will decrease over time due to a process known as degradation. The degradation rate 
depends on the environmental conditions and the technology of the module. Modules are either mounted on fixed-angle frames or on sun tracking frames. Fixed frames are simpler to install, cheaper and require less maintenance. However, tracking systems can increase yield by up to 45 percent. Tracking, particularly for areas with a high direct/diffuse Irradiation ratio also enables a smoother power output.

Inverters convert direct current (DC) electricity generated by the PV modules into AC electricity, ideally conforming to the local grid requirements. They are arranged either in string or central configurations. Central configuration inverters are considered to be more suitable for multi-MW plants. String inverters enable individual string Maximum Power Point Tracking (MPPT)7 and require less specialized maintenance skills. String configurations offer more design flexibility.

It is important to know the measure of daylight accessible at a specific area at a given time. The two basic systems which describe sun based radiation are the solar radiance (or radiation) and solar insolation.

A few benefits are connected with the consumption of renewable energy technologies, Including quite low or no greenhouse-gas emissions, making them a key segment in any environmental change moderation methodology (IPCC, 2011). In the New Policies Scenario, absolute CO2 investment funds over all parts from renewable are 4.1

Gigatonnes (Gt) in 2035. In the power sector, renewable-based generation reduces emissions when it displaces power generation from the combustion of fossil fuels.

Relative to the emissions that would be generated if the growing electricity demands of the New Policies Scenario were to be supplied using the electricity generation mix of 2010, renewable help to reduce $\mathrm{CO} 2$ emissions in the power sector by $3.6 \mathrm{Gt}$ in 2035.

These savings represent some $10 \%$ of the level of emissions reached in 2035, with more than $40 \%$ of the savings coming from increased wind generation. Although hydropower generation increases by about two-thirds over the projection period, its share of total generation declines in many regions, therefore its contribution to $\mathrm{CO} 2$ savings is more limited than other renewable. Heat produced from renewable sources, as in wood pellet or solar heat boilers for example; reduce $\mathrm{CO} 2$ emissions by 150 million tons in 2035 by displacing heat from boilers using coal, oil or gas.Bio fuels reduce emissions from oil in the transport sector by an estimated $0.4 \mathrm{Gt}$ in 2035 but only so long as their production does not result in increases in emissions from direct or indirect land-use changes. This aspect of bio fuels has come under close scrutiny in recent years. Sugarcane ethanol and advanced bio fuels have the highest potential to reduce emissions (IEA, 2011a). Bio fuels have also been criticized for competing with food supply and contributing to deforestation. The negative impacts of bio fuels, however, can be minimized or avoided if the right policies are established and enforced. Renewable energy is largely a domestic source of energy (although some proportion of bio fuels and other bio energy is traded internationally). When it dislodges foreign made powers, it helps more amazing national energy security and specifically decreases import bills, which in turn aid to an 48

DOI: $10.33042 / 2079-424 X-2019-1-54-47-54$ equitably noteworthy rate of GDP in numerous importing nations and frequently help an exchange shortfall.

Bio fuels have the possibility to diminish these impacts fundamentally. In addition, more utilization of renewable energy could in a roundabout way put descending weight on oil and gas costs and decrease value unpredictability. In the electricity sector, renewable mainly reduce the need to import gas or coal, as oil use is limited in this sector.

The use of fossil fuels gives rise to several pollutants that worsen ambient air quality and have a negative impact on human health. Two of the most important of these pollutants are sulphur dioxide (SO2) and nitrogen oxides (NOx); SO2 coming mainly from burning coal but also from diesel fuel, while NOx come from burning all types of fossil fuels. They cause various ecological issues, for example, corrosive rain and ground-level ozone creations. Their effect is neighborhood and local.

Air contamination is a significant issue in a few vast urban communities in non-OECD nations (and in a few urban areas in the OECD). Mix of air quality and renewable energy arrangements might be more powerful than divide movements. A few sorts of renewable energy innovations for power generation require fundamentally less water for their operation than fossil fuel-based and atomic force plants. Solar PV and wind power do not use water to produce electricity and require only small amounts for cleaning purposes. If the significant use of water during the extraction of fossil fuels and uranium is taken into consideration, the differences in water use are even greater. Use of solar PV and wind power also avoids thermal pollution and contamination that may be caused by the discharge of cooling water for thermal power plants.

\section{NOMENCLATURE}

Vpv - output voltage of a PV module (V)

Ipv - output current of a PV module (A)

$\mathrm{Tn}$ - Nominal temperature $=298 \mathrm{~K}$

$\mathrm{T}$ - The module operating temperature in Kelvin

Iph - Photo Current, (A).

Io - The PV module saturation current (A)

$\mathrm{A}=\mathrm{B}$ is an ideality factor $=1.6$.

$\mathrm{K}$ - Boltzman constant $=1.3805 * 10-23 \mathrm{~J} / \mathrm{K}$

q - Electron charge $(C)=1.6 * 10-19 \mathrm{C}$

Rs -The series resistance of a PV module

Isc - the PV module short-circuit current at $25 \mathrm{oC}$ and $1000 \mathrm{~W} / \mathrm{m} 2=8.21 \mathrm{~A}$

$\mathrm{Ki}$ - The short-circuit current of cell at $25 \mathrm{o} \mathrm{C}$ and $1000 \mathrm{~W} / \mathrm{m} 2$

G-The Solar Irradiation $(\mathrm{W} / \mathrm{m} 2)=1000 \mathrm{~W} / \mathrm{m}^{2}$

Ego -The band gap Energhe semi conductor $1.1 \mathrm{eV}$.

Voc; Open Circuits Voltage, 32.9 V.

Rs- Series Resistance, $0.221 \Omega$.

$\mathrm{n}$ - The ideality factor of the diode, 1.3 . 
- Haidar Gafar Abugoukh, Вип. 54, №01.

Rsh-Shunt Resistance, $415.405 \Omega$.

Vt- Diode Thermal Voltage, (V).

Ns -The number of cells connected in series, 54 .

$$
I_{r s}=\frac{I_{s c}}{\exp \left\{\frac{q V o c}{N s K n T}\right\}-1}
$$

$\mathrm{Np}$-The number of PV Modules connected in parallel.

Current through shunt resistor:

IV. MAthematical Model for a Photovoltaic MODULE

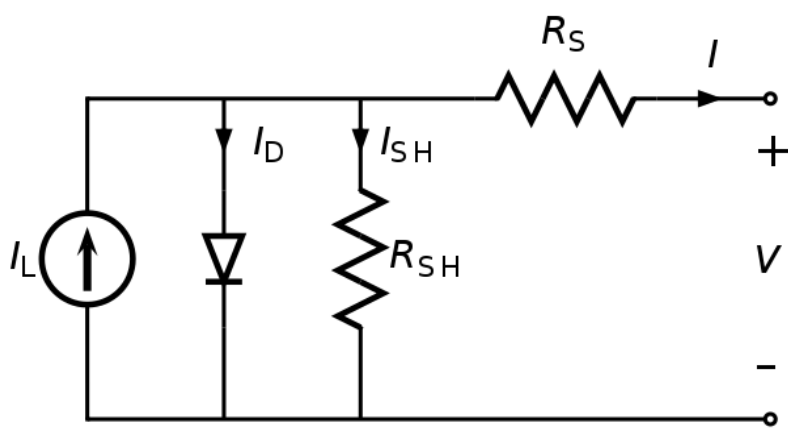

Fig. 1. PV Cell modeled as diode circuit

The most commonly known solar cell is configured as a large-area $p-n$ junction made from silicon; the electromagnetic radiation of solar energy can be directly converted to electricity through photovoltaic effect. Being exposed to the sunlight, photons with energy greater than the band-gap energy of the semiconductor creates some electron-hole pairs proportional to the incident irradiation.

The equivalent circuit of PV cell is as shown in (1)

The an ideal solar cell, it is assumed that $\mathrm{Rs}=0$, Rsh=infinity.The net current of the cell is the difference between the photocurrent Iph and normal diode current which is given by

$$
I=I_{p h}-I o\left\{\exp \left\{\frac{q \cdot\left(V+I_{s}\right)}{n K \cdot N s T}\right\}-1\right\}-I_{\text {sh }}
$$

Module photo-current:

$$
\mathrm{I}_{\mathrm{ph}}=\left[\mathrm{I}_{\mathrm{sc}}+\mathrm{K}_{\mathrm{i}}(\mathrm{T}-298)\right] \cdot \mathrm{G} / 1000
$$

Module saturation current Io varies with the cell temperature, which is given by:

$$
I_{o}=I_{r s} \cdot\left(\frac{T}{T n}\right)^{3} \cdot \exp \left\{\frac{q \cdot \operatorname{Ego}\left(\frac{1}{T n}-\frac{1}{T}\right)}{n K}\right\}
$$

Module reverses saturation current:

$$
\mathrm{Ish}=\left[\frac{(\mathrm{V}+\mathrm{IRs}))}{\mathrm{Rsh}}\right]
$$

\section{REFERENCE MODULE:}

SN72-CELL-POLYCRYSTALLINE PV MODULE iN325P-10 is taken as the reference module for simulation.

\section{TABLE I. ELECTRICAL CHARACTERISTICS DATA OF} SOLKAR325 W PV MODULE

\begin{tabular}{|l|l|}
\hline Rated Power (P max) & $325 \mathrm{~W}$ \\
\hline Voltage at P max (V mp) & $37.3 \mathrm{~V}$ \\
\hline Current at P max & $8.72 \mathrm{~A}$ \\
\hline Short Circuit Current (I sc) & $9.10 \mathrm{~A}$ \\
\hline Open Circuit Voltage (V oc) & $46.0 \mathrm{~V}$ \\
\hline Total number of cells in series (Ns) & 72 \\
\hline Total number of cells in parallel (Np) & 1 \\
\hline
\end{tabular}

Stage A: The module - current through shunt resistor

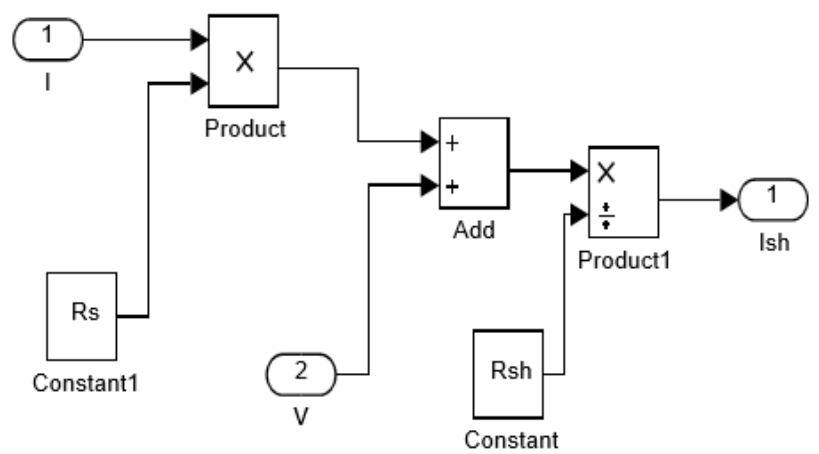

Fig. 2. The module - current through shunt resistor

Stage B:

This module takes reverse saturation current module reference temperature and the module operating temperature as input and calculates module saturation current. 


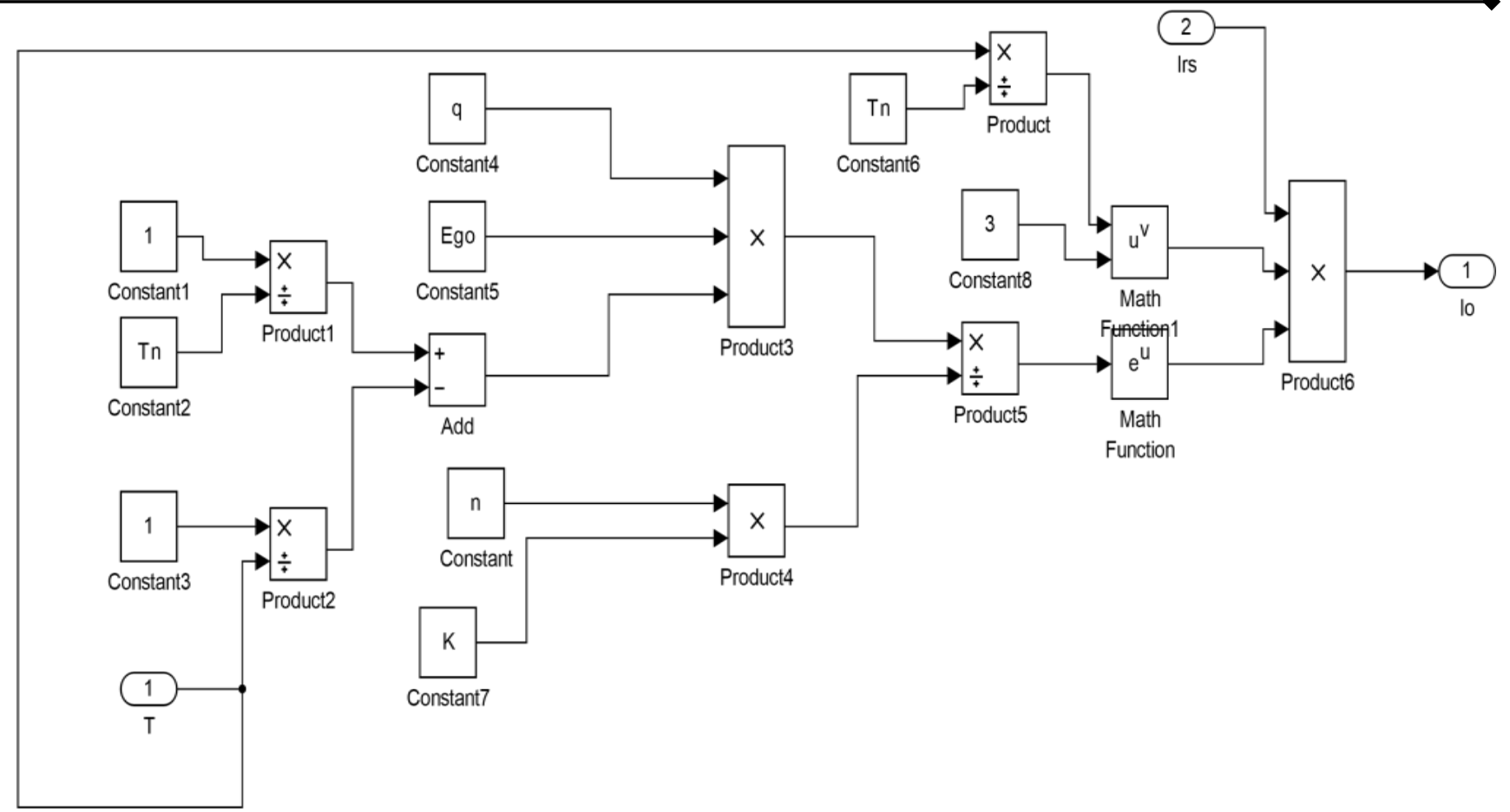

Fig. 3. Using the equation 3 the saturation current:

$$
I_{\mathrm{o}}=\mathrm{I}_{\mathrm{rs}} \cdot\left(\frac{\mathrm{T}}{\mathrm{Tn}}\right)^{3} \cdot \exp \left\{\frac{\mathrm{q} \cdot \operatorname{Ego}\left(\frac{1}{\mathrm{Tn}}-\frac{1}{\mathrm{~T}}\right)}{\mathrm{nK}}\right\}
$$

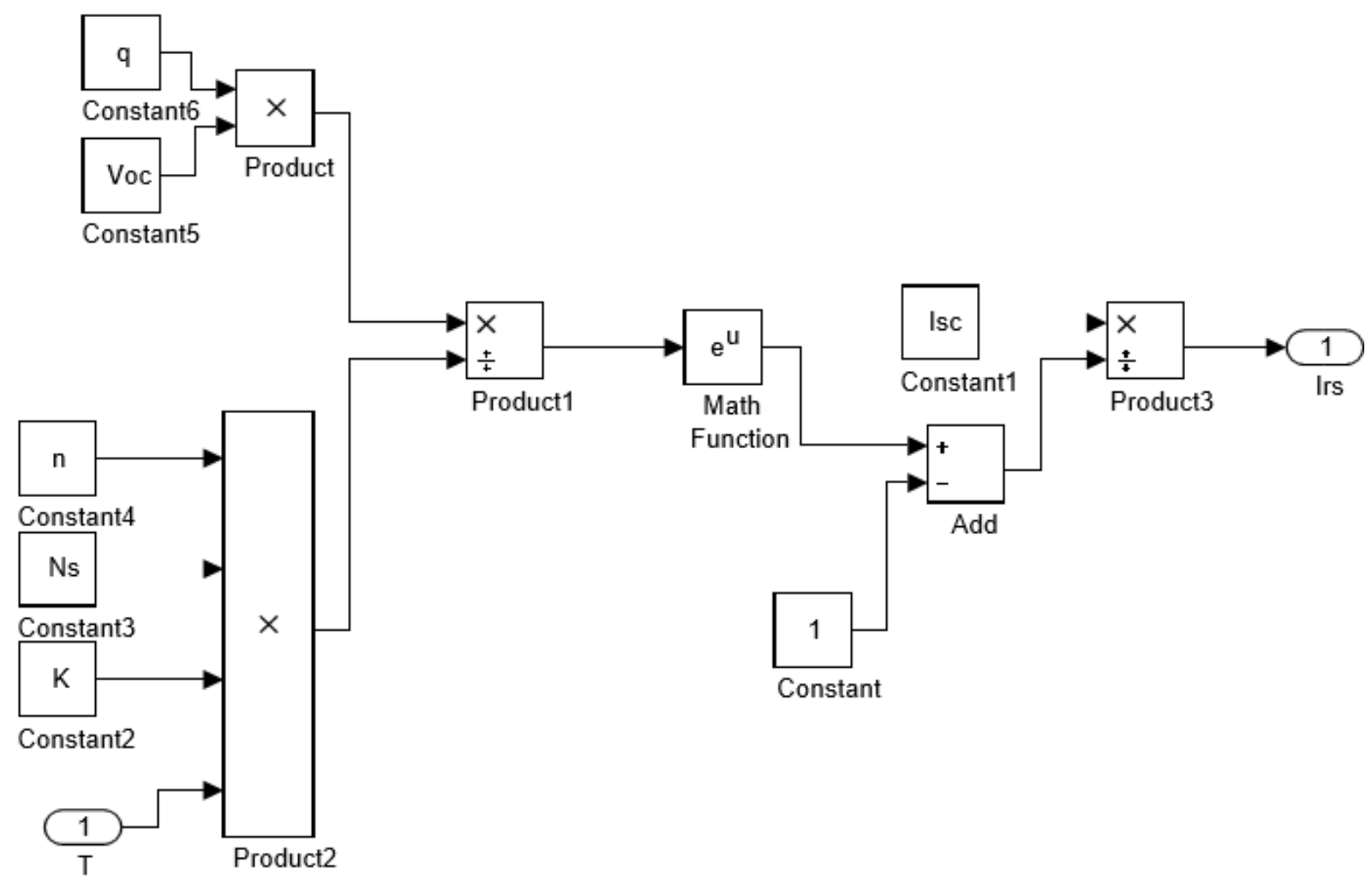

Fig. 4. . This model calculate the reverse saturation current through the diode using equation 4 
Stage D:

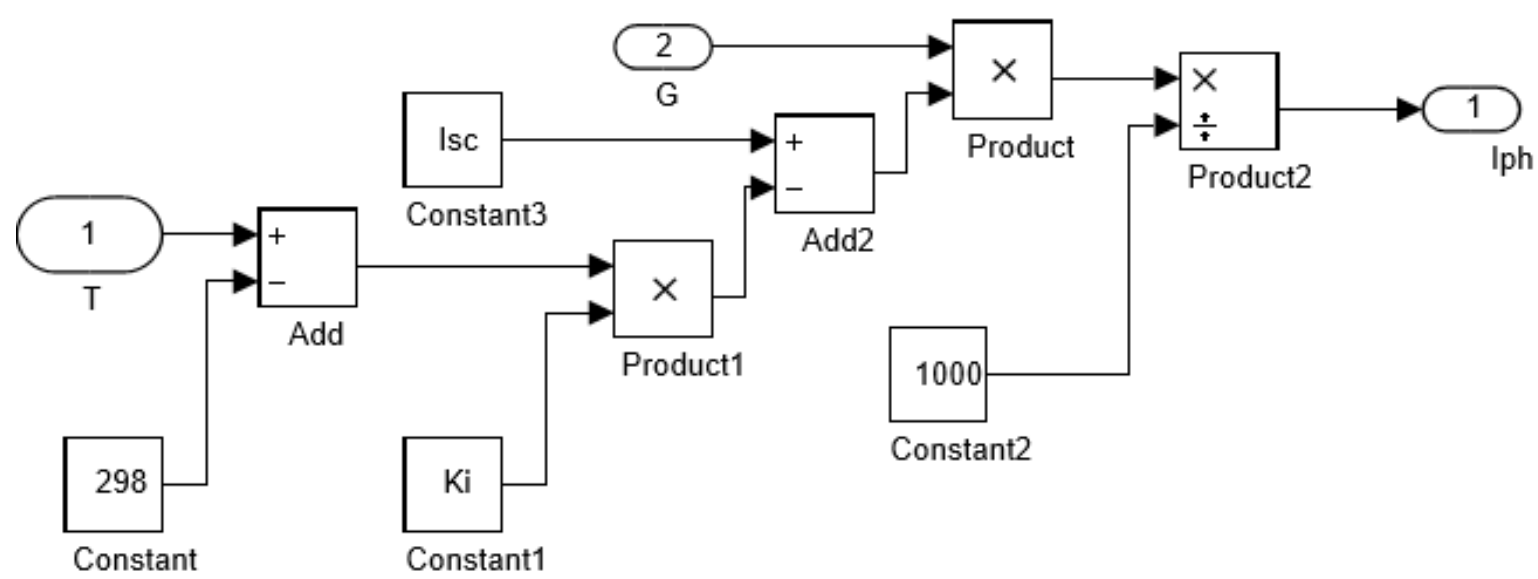

Fig. 5. This module calculate the photo current using equation 2.

Stage E:

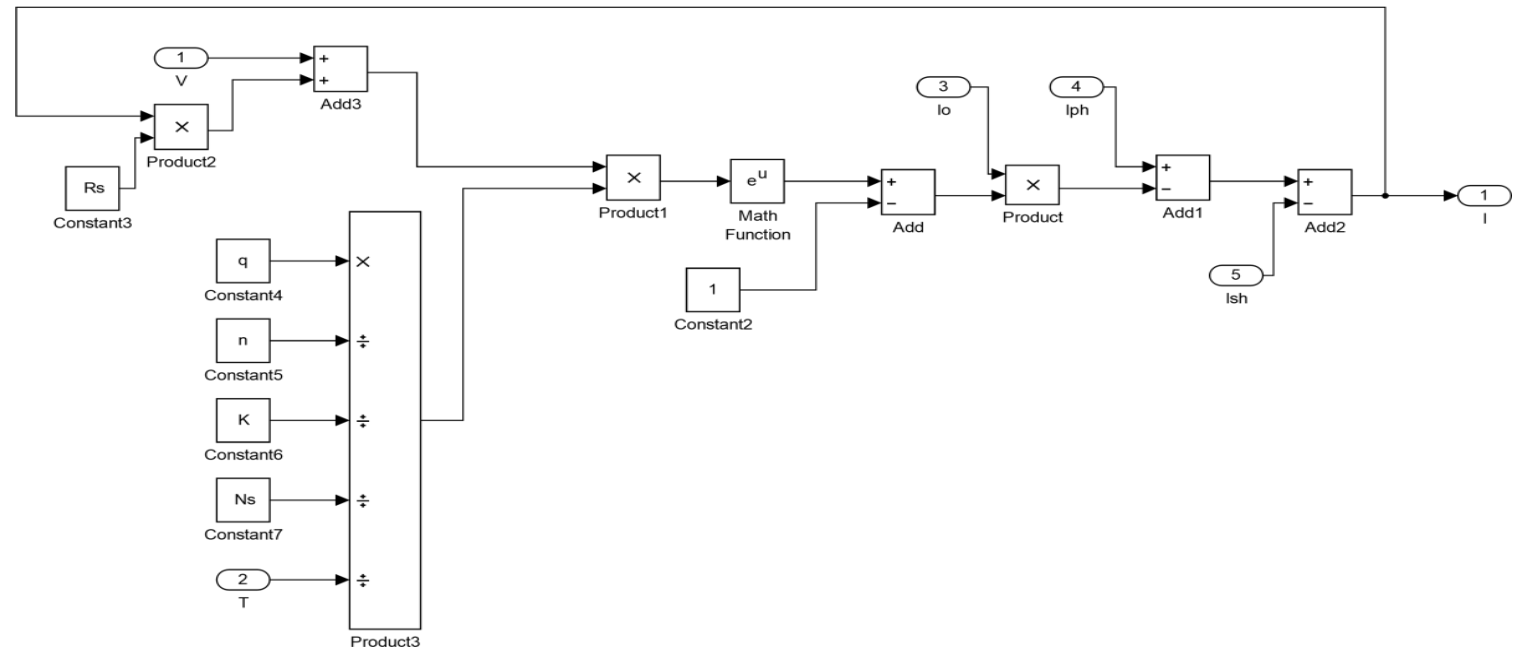

Fig. 6. This module calculates output current using equation 1.

Stage E:

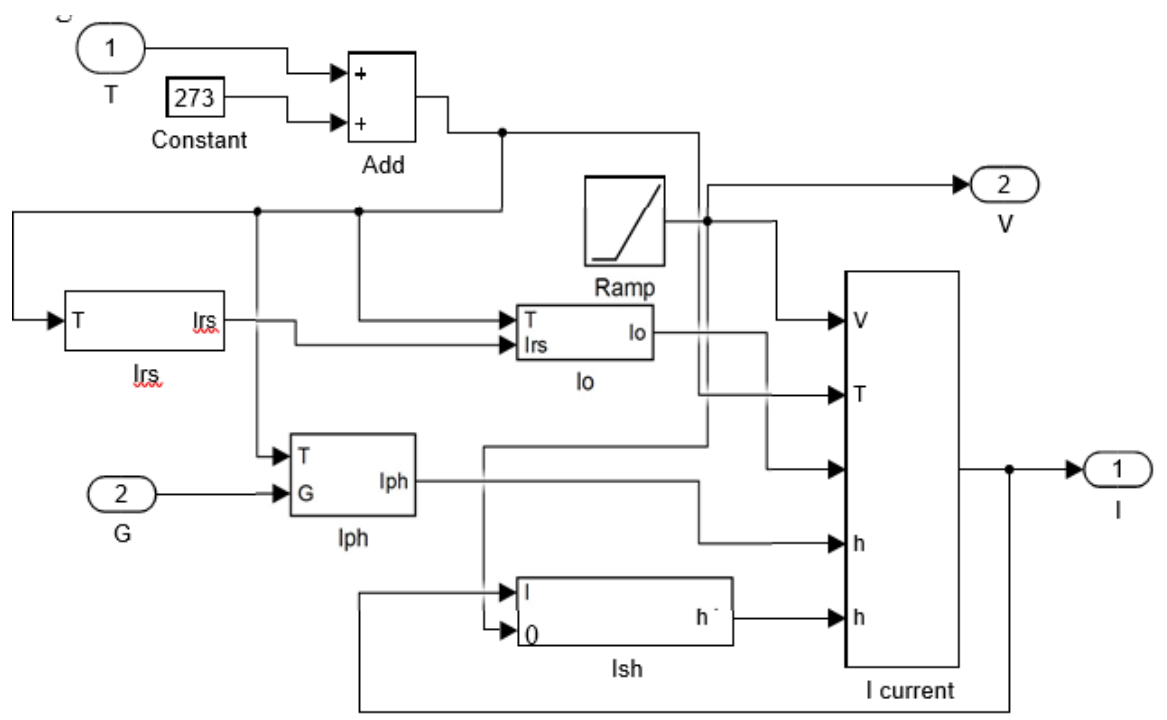

Fig. 7. . This module contains all the six model interconnected together. 


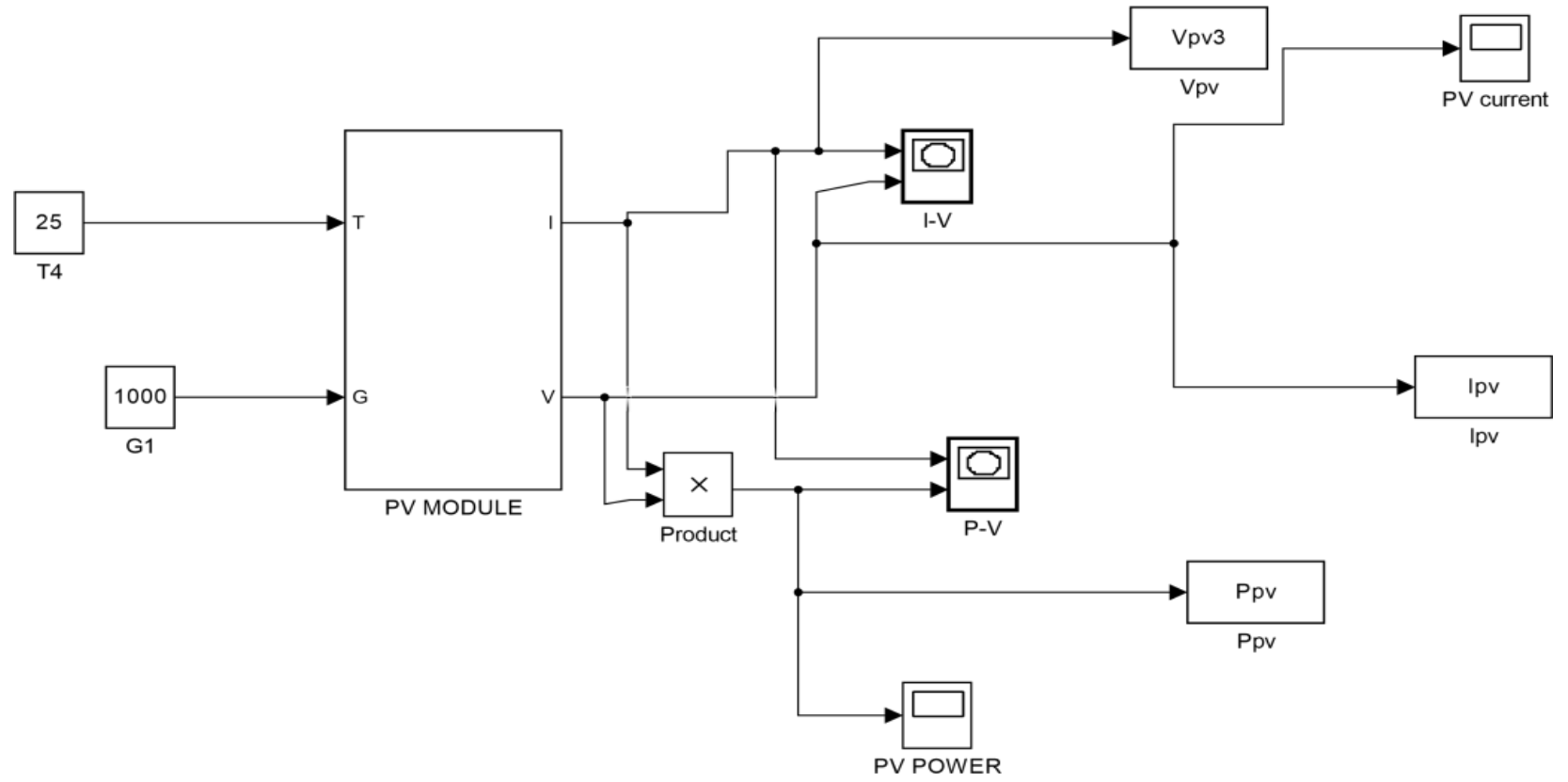

Fig. 8. This module takes irradiation, operating temperature and module voltage as input and gives the output current and output voltage.

\section{The Simulation RESUlts}

\section{Solar Radiation Effects on PV Module:}

As show in (Figure 9-10) .while temperature constant with increase different level of solar radiation (300 W/sq.mm, 500 W/sq.mm, 700 W/sq.mm, and 1000 $\mathrm{W} / \mathrm{sq} . \mathrm{mm})$, the short circuit current of the PV module increased and the maximum power output increased as well.

Temperature Effects on PV Module:

The temperature is an important of solar cell. As shown in (Figure 11,12), while radiation constant with increased temperature of different level $(50 \mathrm{C}, 60 \mathrm{C}, 70 \mathrm{C}, 80 \mathrm{C})$, The short circuit current of PV cell increase ,the maximum power output decreases. When the temperature decreases, the output power and voltage increases marginally whereas the output current almost keeps constant.

As we can see in the figures, the voltage and the power increase are highly effected by the temperature and solar radiation with different values when variable solar radiation with constant temperature, solar radiation constant with variable temperatures.

\section{CONCLUSION}

The above mathematical modeling of PV module with $\mathrm{I}-\mathrm{V}$ and $\mathrm{P}-\mathrm{V}$ characteristics shows:

-The increasing temperature PV module, open circuit voltage (Voc) got decreasing but short circuit current slightly increasing.

- Maximum power decreases with increasing the temperature.

- Voltage produced by PV module at open circuit and current produced at short circuit are increased with increasing the solar irradiance level from $300 \mathrm{~W} / \mathrm{sq} . \mathrm{mm}$. to $1000 \mathrm{~W} / \mathrm{sq} . \mathrm{mm}$.

- The output power PV modules strongly depend on the solar irradiance falling on it.

P-V Characteristic varying irradiance -constant temperature

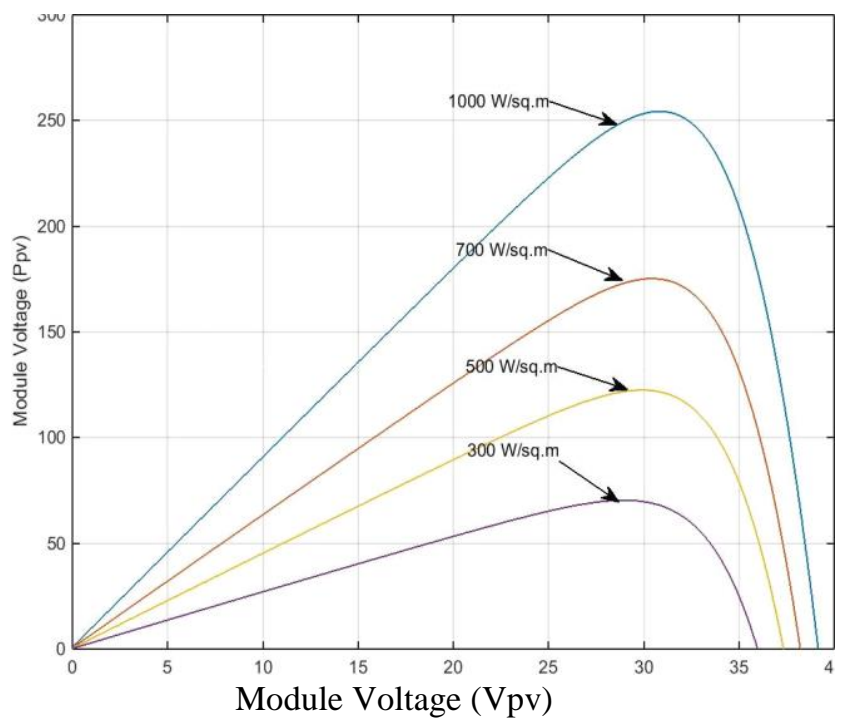

Fig. 9. Characteristic-variable solar radiations -constant temperature.

I-V Characteristic varying irradiance -constant temperature 


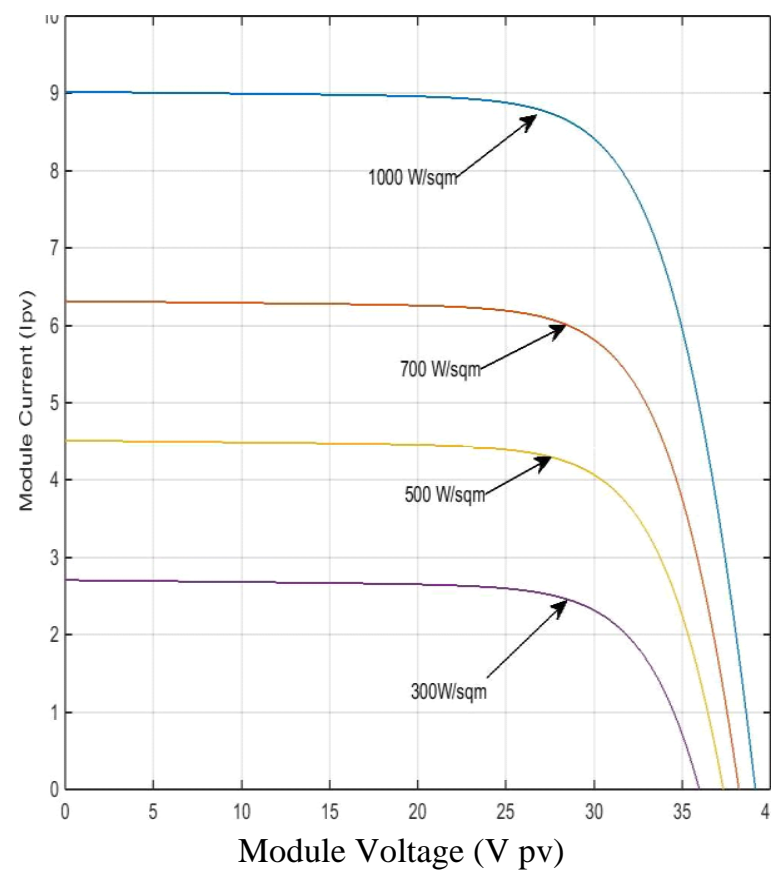

Fig. 10. Characteristic-variable solar radiation-constant temperature

P-V Characteristic -constant solar radiation-variable temperature

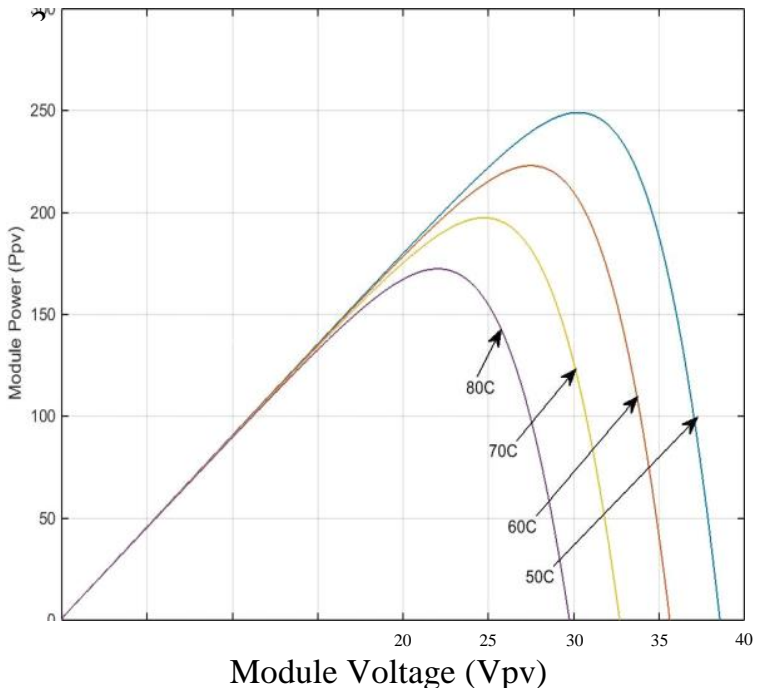

Fig. 11. Characteristic- constant solar radiations variable temperature.

I-V Characteristic -constant solar radiation-variable temperature

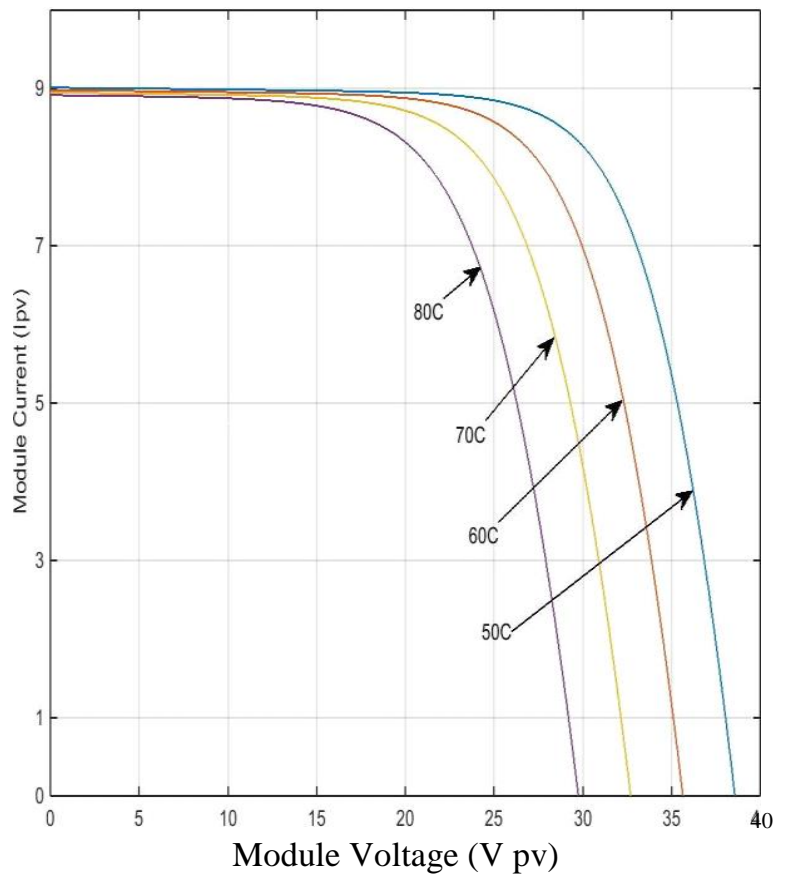

Fig. 12. Characteristic- constant solar radiations - variable temperature.

\section{REFERENCES}

[1] Angelo Baggini University of Bergamo."Handbook of Power Quality",

[2] Dr. Shree Raj Shakya- Sustainable Energy "Technologies (Session 5) Solar Photovoltaic (PV) Technologies-2016".

[3] S. Sumathi • L. Ashok Kumar • PSurekha-"Solar PV and Wind Energy Conversion Systems"-

[4] TAMER KHATIB , WILFRIED ELMENREICH -"Modeling of Photovoltaic Systems using Matlab,2016"

[5] STATE OF ENERGY REPORT - Dubai 2014, www.dcce.ae/energyreport.

[6] D.V. Tugay, Yu.P. Kolontaevsky, S.V. Kotelevets, Ye.S. Savchuk "SOLAR POWER PLANT OPERATION MODELING IN SMART GRID ELECTRICITY SUPPLY SYSTEM “-

[7] Ismail H. Altas and Adel M. Sharaf."Solar Energy and PV Systems

[8] Pandiarajan N. and Ranganath Muthu. 2011. "Mathematical modeling of Photovoltaic module with Simulink".

[9] Xuan Hieu Nguyen andMinh Phuong Nguyen' "Mathematical modeling of photovoltaic cell/module/arrays with tags in Matlab/Simulink",

[10] Mohammed, S.S, "Modelling and Simulation of Photovoltaic Module using MATLAB/Simulink",

[11] Alsayid, B. and Jallad, J. "Modelling and Simulation of Photovoltaic Cells/Modules/ Arrays'.

[12] Oluwaseun M. Akeyo "PHOTOVOLTAIC SYSTEMS INCORPORATING BATTERY ENERGYSTORAGE".

[13] Longatt, F.M.G, "Model of Photovoltaic Module in Matlab".

\title{
Математичне моделювання фотоелектричного модуля 3 Simulink
}

\author{
Хайдар Гафар Абугоух
}

Харківський національний університет імені О.М. Бекетова

Харків, Україна 
Сонячна енергія $\epsilon$ хорошим вибором для виробництва електроенергії, оскільки сонячна енергія безпосередньо перетворюється в електричну енергію сонячними фотоелектричними модулями Сонячні клітини виробляють більшу частину своєї електроенергії від прямих сонячних променів. Однак вони також виробляють електроенергію у похмурі дні, а деякі системи можуть навіть генерувати дуже невеликі кількості електроенергії у світлі місячні ночі. Окремі сонячні батареї, як правило, генерують лише невеликі кількості електричної енергії. Для отримання корисної кількості електроенергії ці комірки з'єднуються між собою, щоб зробити сонячний модуль, інакше відомий як сонячна панель або, точніше, фотоелектричний модуль. Модель PV відіграє важливу роль у точності часове моделювання моделі фотоклітин. Моделювання фотоелементів включає оцінку кривих характеристик I - V та $\mathrm{P}-\mathrm{V}$ для імітації реальної комірки в різних умовах навколишнього середовища Фотоелектрична модель (PV) використовується в симуляційному дослідженні для перевірки конструкції системи PV-система. У цій роботі представлено моделювання фотовольтаїчного (PV) модуля за допомогою МАTLAB / SIMULINK. Модель розроблена на основі математичної моделі PV-модуля. PV-модуль SN72-CELL-POLY CRYSTALLINE PV MODULE SN325P обраний для експериментальних та технічних даних для аналізу розробленої моделі. Криві вихідного струму та потужності сильно залежать від деяких кліматичних факторів, таких як сонячне випромінювання та температура, одержувані шляхом моделювання для вибраного модуля з вихідною потужністю 325 Вт. Завданням даної роботи є розробка модель для імітації поведінки фотоелектричної комірки. Досягнуті значення напруги та струму Voc за характеристиками I-V та P-V порівнюються 3 інформаційними таблицями модулів, обидві моделі реалізовані в MATLAB / SIMULINK. "П'ятипараметрична модель" модель продуктивності для фотоелектричних сонячних батарей, яка прогнозує напругу та вихід струму, представляючи комірки як еквівалентну електричну ланцюг із компонентами, що залежать від випромінювання та температури. Важливою особливістю п'ятипараметричної моделі $\epsilon$ те, що ії параметри можна визначати, використовуючи дані, що зазвичай надаються виробниками модулів у своїх опублікованих таблицях даних. 